\title{
Corrigendum: Surface-bound chemokines capture and prime T cells for synapse formation
}

Rachel S Friedman, Jordan Jacobelli \& Matthew F Krummel

Nature Immunology 7, 1101-1108 (2006); published online 10 September 2006; corrected after print 29 September 2006

In the version of this article initially published, the label at the far right of the horizontal axis of Figure 5a is incorrect. The correct label should be $\alpha-\beta_{1}$. The error has been corrected in the PDF version of the article.

\section{Corrigendum: Clonal deletion of thymocytes by circulating dendritic cells homing to the thymus}

\section{Roberto Bonasio, M Lucila Scimone, Patrick Schaerli, Nir Grabie, Andrew H Lichtman \& Ulrich H von Andrian}

Nature Immunology 7, 1092-1100 (2006); published online 3 September 2006; corrected after print 29 September 2006

In the version of this article initially published, the third sentence in the legend of Figure 6 is incorrect. The correct sentence should read " $\star, P<0.01$, and ${ }^{* *}, P<0.001$, compared with DCs”. In the last sentence of the legend to Figure 8, 'obtainted' should read 'obtained'. On page 1098, in the first sentence of the first full paragraph, 'fused' should read 'used'. These errors have been corrected in the HTML and PDF versions of the article. 